\title{
THE EFFECT OF PRICE BEHAVIOUR ON INDONESIAN CPO EXPORT QUANTITY
}

\author{
Putri Budi Setyowati ${ }^{1}$, Dessanty Fauziah Widayat ${ }^{2}$, Budi Prihatminingtyas ${ }^{2}$ \\ ${ }^{1}$ Dept. of Agricultural Socio Economics, Brawijaya University, Jln Veteran, Malang, Indonesia \\ ${ }^{2}$ Dept. of Economics, Tribhuwana Tunggadewi University, Jln Telaga Warna, Malang, Indonesia \\ Correspondence Email: putri budi@ub.ac.id
}

Submitted 27 Januari 2020; Accepted 17 November 2020

\begin{abstract}
ABSTRAK
Perubahan penawaran dan permintaan yang tidak terduga dapat menyebabkan variasi perilaku harga. Crude Palm Oil sebagai komoditas ekspor utama Indonesia memiliki risiko tertinggi pada ketidakpastian harga yang dipengaruhi oleh harga dunia yang kecenderungannya yaitu berfluktuasi dan lama kelamaan akan volatil pada periode tertentu. Dalam rangka meningkatkan produksi CPO, pemerintah telah menerapkan peraturan wajib biodiesel yaitu B30 pada tahun 2019. Ini berarti penggunaan bahan bakar diesel dengan kandungan biofuel 20 persen. Selain itu, pemerintah juga telah menerapkan kebijakan pajak nol persen untuk mendorong produsen CPO dalam melakukan ekspor. Tujuan dari penelitian ini adalah untuk menganalisis volatilitas harga dan pengaruhnya terhadap volume ekspor dalam jangka panjang. Harga CPO harian Indonesia sejak Januari 2010 hingga Desember 2017 dianalisis dengan Metode Volatilitas Historis dan Uji Kointegrasi. Hasil dari penelitian ini bahwa harga $\mathrm{CPO}$ domestik dan dunia cenderung tinggi sedangkan harga domestik lebih tidak stabil dibandingkan harga dunia. Selain itu, harga CPO dan volume ekspor dikointegrasi dan memiliki hubungan negatif dalam jangka panjang.
\end{abstract}

Kata Kunci: volatilitas harga, kuantitas ekspor, $C P O$

\begin{abstract}
Unpredictable changes in supply and demand may cause the variation of price behavior. Crude Palm Oil (CPO) as Indonesian main export commodity has the highest risk of uncertainty price which is influenced by world price while it tends to fluctuate and become volatile in the given period. In order to increase CPO production, government has implemented biodiesel mandatory regulation namely B30 in 2019. It means that the use of diesel fuel with 20 percent of biofuel content. Besides that, government also applies zero tax policy to stimulate CPO producers in doing export. The objectives of this research are to analyze price volatility and its effect on export volume in the long term. Daily Indonesian CPO price since January 2010 to December 2017 was analyzed by Historical Volatility Method and Cointegration Test. This research shows that both domestic and world price of CPO tends to be high while domestic price is less volatile than world price. Furthermore, CPO's price and export volume are cointegrated and have negative relation in the long term.
\end{abstract}

Keywords: price volatility, export quantity, $\mathrm{CPO}$

\section{INTRODUCTION}

Indonesia becomes the largest CPO exporter since 2009 according to the data provided by FAO in Kementerian Pertanian (Kementan) outlook of palm oil and dominates palm oil production in the world by contributing $47.16 \%$ with its volume about 17.78 million tons per year (Kementan, 2016). In line with the increase of world population growth, CPO demand will also increase which will consequently increase palm oil consumption. Its demand will definitely continue to increase. In order to 
fulfil domestic and world demands, farmers need to increase its production by enlarging farm size. Since 1980 to 2016, Ministry of Agriculture stated that the average growth of increasing farm size is $10.99 \%$ per year. In consequence, its average production is $11.50 \%$ per year. However, percentage of productivity growth rate is not as many as its production. It tends to fluctuate and as many as $0.64 \%$ per year (Kementan, 2016).

Related to CPO global price, it has fluctuated with a decrease of 0.8 per cent and will affect local CPO price (Chen, 2018). If it occurs over a period, it will cause price volatility which is a measurement of commodity price or quantity variability (FAO et al., 2011). Moreover if price volatility continuously occurs then quantity of supply and demand will not be easily estimated (Gilbert and Morgan, 2010). Since CPO is a price leader among any other selected palm oil products and it has moderate or even high volatility price since last 10 years, an effort to stabilize its price in order to minimize volatility should be made (Rahman et al., 2007; Zainal, Arindra et al, 2012; Pramana and Anggono, 2014; Bergmann, O’Connor and Thümmel, 2016).

Volatility of agricultural products has a strong relation with economic crises. If its volatility tends to be high, it will cause economic crises, for instance lack of food, poverty rate will increase, and social economic welfare tends to be decreased (Miguez and Michelena, 2011). In other words, price volatility is able to obstruct economic growth which is influenced by export and import.

Indonesian $\mathrm{CPO}$ is dominantly exported to India, China, Pakistan, Netherland, Malaysia, Egypt, and Bangladesh (BPS, 2016). The imposition of export tax in a country tend to increase export price and decrease local price (Chen, 2018). However, for a country who has market bargaining power, it will take a part in determining world price, export quantity, and income distribution (Helpman and Krugman, 1985).
Determination of Indonesian $\mathrm{CPO}$ export tax depends on CPO product reference price. Based on data taken from Ministry of Trade Indonesia (2018), this price is 697.34 $\mathrm{USD} /$ ton, lower than $750 \mathrm{USD} /$ ton which is the minimum reference price leading to a decrease of $6.14 \%$. Moreover since 2014, it has always been lower than the minimum reference price. That is why, government has been applying $0 \mathrm{USD} /$ ton for CPO export tax in order to support CPO exporters and stabilize CPO price. Otherwise, export quantity tends to decrease, thus domestic supply will increase. In consequence, it will affect domestic price.

Since CPO price is volatile, it reflects business risk in palm oil industry because this is able to raise uncertainties that makes financial and strategic planning become more difficult. Moreover, Indonesia is not able to be CPO's price taker yet even though becomes world's largest exporter. Its price is referred by Rotterdam CPO Price which represents $\mathrm{CPO}$ world price. In the manner of this, this study is aimed to analyse domestic and world price volatility and whether it affects export volume or not.

\section{RESEARCH METHODS}

Daily data of domestic and world $\mathrm{CPO}$ price from was used in this study from Commodity Futures Trading Regulatory Agency (BAPPEBTI). Period of domestic price is from 2010 to 2018 in Rupiah (Indonesian currency) while data of international CPO price from 2010 to 2017 had been converted by Indonesian exchange rate from the central bank of Indonesian Republic in the given period. On the other hand, data of CPO export quantity from 2010 to 2017 was also collected from Directorate General of Estate Crops.

\section{CPO Price Volatility}

In order to analyze domestic and world price volatility, Historical Volatility Method was applied to measure price fluctuation by calculating mean and standard 
deviation over the time (Sekhar, 2003; d'Hôtel, Elodie Maitre. Le Cotty, Tristan. Jayne, 2012; Minot, 2014). The higher deviation standard, the higher price volatility (Junaidi, 2013). Price volatility is high if price variation has very wide range, while its variation tends to be constant then its volatility is categorized as low. Annual price variability was calculated in the average of 12 months and its growth was calculated in $\log \left(\frac{P_{t}}{P_{t-1}}\right)$. In general, formula in historical volatility method can be seen as following:

$$
\begin{aligned}
& m=\left(\frac{1}{n}\right) \sum_{i=1}^{n} X i \\
& \sigma=\sqrt{\frac{1}{n-1} \sum_{i=0}^{n}(m-X i)^{2}}
\end{aligned}
$$

Where:

$$
\begin{array}{ll}
\sigma & =\text { standard deviation or Historical } \\
& \text { volatility } \\
\mathrm{n} & =\text { period } \\
\mathrm{m} & =\text { mean } \\
\mathrm{Xi} & =\text { price variability }
\end{array}
$$

\section{Influence of Price Volatility in Export} Quantity

\section{Stationary Test (Unit Root Test)}

Stationary test in time series analysis needs to be considered because it can generalize the research results to other time periods and prevent the phenomenon of spurious or nonsense regression (Gujarati, 2011). There are basically three ways in examining whether or not research data is stationer: graphical analysis, correlogram, and unit root analysis. Among these three test, unit root analysis which is known as Augmented Dicky-Fuller Test was used and can be expressed as follows:

Where:

$$
Q_{t}=b_{0}+b_{1} P_{v}+U_{t}
$$

$\mathrm{Q}_{\mathrm{t}} \quad=$ export quantity in the $\mathrm{t}$-period.

$\mathrm{b}_{0} \quad=$ constant

$\mathrm{U}_{\mathrm{t}} \quad=$ disturbance term

Hypothesis:

$\mathrm{H}_{0}: \mathrm{b}_{1}=0$, (not stationary)

$\mathrm{H}_{\mathrm{a}}: \mathrm{b}_{1}<0$, (stationary)
This hypothesis has criteria, if $\mathrm{DF}_{\text {stat }}<$ $\mathrm{DF}_{\text {table }}$ or probability value $>$ alpha value then $\mathrm{H}_{0}$ will be accepted and it means that the research data is not stationary and vice versa.

\section{Cointegration Test}

Cointegration test is used to analyze whether or not there is a relation between price volatility and Indonesian CPO quantity export by regressing residual of price volatility variable and export quantity. It can be seen as follows:

Where:

$$
S_{t}=\alpha_{0}+\alpha_{1} P_{t}+\varepsilon_{t}
$$

$\mathrm{S}_{\mathrm{t}} \quad=$ Export quantity in the $\mathrm{t}$-period

$\alpha=$ Constant

$\mathrm{P}_{\mathrm{t}}=$ Price volatility in the t-period (\%)

$\mathrm{E}_{\mathrm{t}}=$ disturbance term

Hypothesis:

\section{$\mathrm{H}_{0}: \mathrm{b}_{1}=0$, (not cointegrated) \\ $\mathrm{H}_{\mathrm{a}}: \mathrm{b}_{1}<0$, (cointegrated)}

This hypothesis has criteria, if $\mathrm{ADF}_{\text {stat }}<\mathrm{ADF}_{\text {table }}$ or probability value $>$ alpha value then $\mathrm{H}_{0}$ will be accepted and it means variable of price volatility and export quantity are not cointegrated. Vice versa, if $A \mathrm{ADF}_{\text {stat }}>\mathrm{ADF}_{\text {table }}$ then $\mathrm{H}_{0}$ will be rejected and it means that these two variables are cointegrated.

\section{RESULTS AND DISCUSSION}

\section{Domestic and World Price Volatility}

Average growth of monthly prices for domestic and world CPO price from 20102017 can be seen in Table 1.

Price behaviour of agricultural product price can be determined by some factors for instance supply and demand. If these factors change, it can fluctuate price of agricultural product. According to the table above, domestic and world price has been fluctuating. Moreover, their volatility growth is illustrated by Figure 1.

According to Figure 1, both domestic and world price are volatile and world price has wider range than domestic price illustrating that world price is more volatile. 
Table 1. Monthly Prices for Domestic and World CPO Price 2010-2017

\begin{tabular}{|c|c|c|c|c|c|c|c|c|}
\hline \multirow[t]{2}{*}{ Year } & \multicolumn{2}{|c|}{ Average Price (Rp/Ton) } & \multicolumn{2}{|c|}{ Domestic Price (Rp/Ton) } & \multicolumn{2}{|c|}{ World Price (Rp/Ton) } & \multicolumn{2}{|c|}{ Standard Deviation } \\
\hline & Domestic & World & Max & Min & Max & Min & Domestic & World \\
\hline 2010 & $7,815,940$ & $8,053,775$ & $10,308,400$ & 6,920, & $10,904,438$ & $6,648,650$ & 0.057 & 0.067 \\
\hline 2011 & 8,9 & 10,02 & & & & & 63 & 118 \\
\hline 2012 & 8 & 3 & 10, & 6 & 2 & 7 & 8 & 054 \\
\hline 2013 & 8 , & 9 , & 10 & 1 & 10, & 8 & 2 & 01 \\
\hline 2014 & $8,937,511$ & $10,093,893$ & $10,222,650$ & $7,623,333$ & $13,803,082$ & $8,402,787$ & 0.044 & 0.155 \\
\hline 2015 & $7,386,922$ & $8,437,959$ & $8,450,952$ & $5,892,900$ & $10,136,040$ & $7,551,385$ & 0.080 & 0.115 \\
\hline 2016 & $8,523,008$ & $9,177,942$ & $9,910,250$ & $6,723,750$ & $10,406,142$ & $7,874,120$ & 0.061 & 0.053 \\
\hline 2017 & $8,876,922$ & $9,424,938$ & $10,365,620$ & $8,113,556$ & $10,636,454$ & $8,706,393$ & 0.053 & 0.046 \\
\hline
\end{tabular}

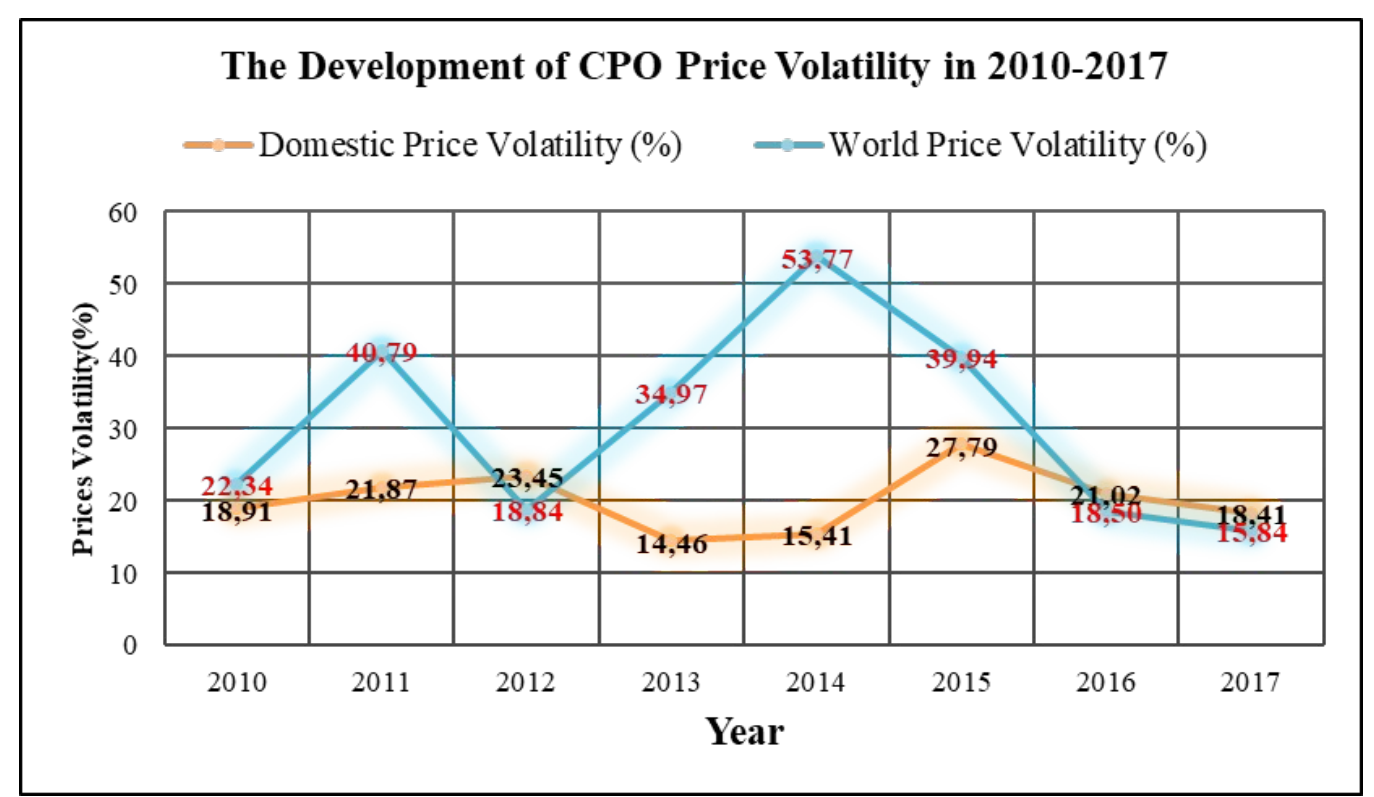

Figure 1. Domestic and World CPO Price Volatility Growth

It can also be seen that movement of domestic price volatility follows that of world price which refers to the existence of price movement by the law of one price (LOP) (Chen, 2018). Hence, CPO domestic price can be determined by CPO world price.

Effect of CPO Price Volatility on Export Quantity

Stationary Test

Stationary test is becoming the first step to examine whether the research data is stationary or not using ADF Test that can be seen in Table 2.

In the level (0), export quantity has probability value which is more than 0.1 (alpha value) then it is not stationary while probability value of price volatility is less than 0.1 then it is stationary. Non stationary variables in the level (0) indicates that there is strong correlation between these two variables. If it is not stationary then it has to be transformed into difference form by calculating the difference between two periods.

Table 2. Result of Stationary Test

\begin{tabular}{lcccccc}
\hline \multirow{2}{*}{ Variable } & \multicolumn{2}{c}{ Level (0) } & \multicolumn{2}{c}{$1^{\text {st }}$ Difference (1) } & \multicolumn{2}{c}{$2^{\text {nd }}$ Difference (2) } \\
& t-stat & Prob. & t-stat & Prob. & t-stat & Prob. \\
\hline Export Quantity & -2.3317 & 0.1906 & -1.0336 & 0.6622 & -2.9884 & 0.0994 \\
Price Volatility & -3.2613 & 0.0664 & -3.3455 & 0.0697 & -16.9496 & 0.0002 \\
\hline
\end{tabular}


Table 3. Result of Cointegration Test in Level (0) and $1^{\text {st }}$ Difference (1)

\begin{tabular}{|c|c|c|c|c|c|c|c|c|c|}
\hline \multicolumn{5}{|c|}{ Level (0) } & \multicolumn{5}{|c|}{$1^{\text {st }}$ Difference (1) } \\
\hline Dependent & Variable & DRESI & & & Dependen & Variable & RESII & & \\
\hline Variable & Coef & $\begin{array}{c}\text { Std. } \\
\text { Error }\end{array}$ & $\mathrm{t}-\mathrm{Stat}$ & Prob. & Variable & Coef & $\begin{array}{l}\text { Std. } \\
\text { Error }\end{array}$ & t-Stat & Prob. \\
\hline RESID02 & -0.340 & 0.481 & -0.708 & 0.5108 & RESID04 & -0.500 & 0.520 & -0.963 & 0.3903 \\
\hline C & 0.017 & 0.124 & 0.136 & 0.8973 & $\mathrm{C}$ & 0.037 & 0.132 & 0.280 & 0.7933 \\
\hline
\end{tabular}

Table 4. Result of Cointegration Test in $2^{\text {nd }}$ Difference (2)

\begin{tabular}{lcccc}
\hline \multicolumn{2}{l}{ Dependent Variable: DRESID05 } & & & \\
\hline Variable & Coefficient & Std. Error & t-Statistic & Prob. \\
\hline RESID06 & -1.055 & 0.441 & -2.390 & 0.0968 \\
C & 0.074 & 0.123 & 0.599 & 0.5914 \\
\hline
\end{tabular}

This estimation should be done by cointegration test, but needs to meet the requirement in which all variables are stationary in the same integration order. In the $2^{\text {nd }}$ Difference (2), both variables are stationary which have probability value less than $10 \%$. Thus, the requirement has been fulfilled.

\section{Cointegration Test}

Cointegration test is used to analyze whether there is long term relation between CPO price volatility and export quantity. This test was done by regressing residual of these two variables and the results can be seen in Table 3.

CPO price volatility and export quantity are not stationary in Level $(0)$ and $1^{\text {st }}$ Difference (1) because their probability value is bigger than 0.1 then they are not cointegrated. For this reason, it should be doing cointegration test in $2^{\text {nd }}$ Difference (2) and its result is illustrated in Table 4.

In $2^{\text {nd }}$ Difference (2), probability value is more than 0.1 and significance in $10 \%$ confidence level then CPO price volatility and export quantity are cointegrated. Moreover, variable of RESID06 has negative sign indicating that these two variables have negative relation in the long term. If there is uncertainty CPO price in the long term, then export quantity will decrease. The value of volatility represents price risk of agricultural products. High value of volatility means price goes up high quickly then suddenly drops very quickly and vice versa. It will give very large difference between the lowest price and the highest price at a time. For this reason, it will affect farmers to decrease their export quantity. CPO In order to prevent a decrease in export quantity, an effort should be done by stabilizing CPO price. For this reason, zero tax has been applied in the beginning of 2018 . This regulation will affect domestic CPO price related to raw material supply for domestic producer and exporters will be expected to export more. In consequence, CPO demand will increase and farmers' welfare could be achieved.

\section{CONCLUSION}

Growth of domestic and world CPO price from 2010 tends to be unstable then it can be categorized as having high volatility. World price is more volatile than domestic price and volatility pattern of domestic price follows that of world price. In addition, price volatility and export quantity has negative relation in the long term. If its volatility is getting higher, than export quantity tend to fall. In order to prevent this, zero tax regulation is the right decision to stimulate export quantity so that farmers' welfare can be reached. 


\section{REFERENCES}

Badan Pusat Statistika. 2016. Produk Domestik Bruto Indonesia Tri Wulanan 2012-2016. Jakarta: Badan Pusat Statistika.

Bergmann, D., D. O'Connor and A. Thümmel. 2016. An analysis of price and volatility transmission in butter, palm oil and crude oil markets. Agricultural and Food Economics 4(23). doi: 10.1186/s40100-016-00674.

Chen, J. K. 2018 Price transmission and the effect of Indonesia' $\mathrm{s}$ export tax on crude palm oil (CPO) prices. The International Journal of Business \& Management 6(4): 98-106.

d'Hôtel, E. M., T. L. Cotty and T. Jayne. 2012. Is a public regulation of food price volatility feasible in Africa? an arch approach in Kenya. 123rd EAAE Seminar: 1-16.

FAO, IFAD, IMF, OECD, UNCTAD, WFP, the World Bank, the WTO, IFPRI and the UN HLTF. 2011. Price volatility in food and agricultural markets: policy responses. Policy report.

Gilbert, C. L. and C. W. Morgan. 2010. Food price volatility. Philosophical Transactions of The Royal Society B. Retrieved from https://doi.org/10.1098/rstb.2010.0139

Gujarati, D. 2011. Econometric by Example. New York. Palgrave Macmillan.

Junaidi, E. 2013. Analisis volatilitas harga minyak sawit dan harga minyak goreng. Thesis. Institut Pertanian Bogor. Bogor.

Helpman, E. and P. R. Krugman. 1985. Market structure and foreign trade. MIT. Cambrige.

Kementerian Pertanian. 2016. Outlook Kelapa Sawit. Jakarta: Pusat Data dan Sistem Informasi Pertanian
Presemendag. 2018. Periode Januari 2018: Harga melemah, BK CPO Nol, BK Kakao $\quad 0 \%$. Available at http://www.kemendag.go.id/files/pdf/2 017/12/28/periode-januari-2018-hargamelemah-bk-cpo-nol-bk-kakao-0-id01514452025.pdf

Miguez, I. D. and G. Michelena. 2011. Commodity price volatility: the case of agricultural products. Centro de Economia Internacional: 1-22.

Minot, N. 2014. Food price volatility in subSaharan Africa: Has it really increased ?. Food Policy 45: 45-56.

Pramana, P. G. and Anggono, A. H. 2014. Volatility analysis international crude palm oil price 2004 - 2014. Proceedings of 7th Asia-Pacific Business Research Conference.

Rahman, A. K. A., F. M. Shariff, R. Abdullah and N. F. Sharif. 2007. Price volatility spill over in the Malaysian palm oil industry. Oil Palm Industry Economic Journal 7(1): 24-32.

Sekhar, C. S. C. 2003. Volatility of agricultural prices - An analysis of major international and domestic markets. Working Paper Indian Council for Research on International Economic Relations Number 103: 175.

Zainal, A., Falianty, T. Aulia, D. Sulistyorini, R. Triandari, M. Nopiana and M. Andhonie, M. 2012. Dealing With Commodity Price Volatility in East Asia. Draft of Final Report Ministry of Finance and Asean Secretariat. 